\title{
Effect of Plant Harvesting on the Performance of Constructed Wetlands during Summer
}

\author{
Zhongchen Yang ${ }^{1, \dagger}$, Qian Wang ${ }^{2,+}$, Jian Zhang ${ }^{1, *}$, Huijun $\mathrm{Xie}^{3}$ and Suping Feng ${ }^{1}$ \\ Received: 24 November 2015; Accepted: 8 January 2016; Published: 16 January 2016 \\ Academic Editors: Alan Howard and Defu $\mathrm{Xu}$ \\ 1 School of Environmental Science and Engineering, Shandong University, Jinan 250100, China; \\ yzcgaara@163.com (Z.Y.); fengsp@sdu.edu.cn (S.F.) \\ 2 College of Geography and Environment, Shandong Normal University, Jinan 250014, China; \\ wangqian19860518@163.com \\ 3 Environment Research Institute, Shandong University, Jinan 250100, China; xiehuij@sdu.edu.cn \\ * Correspondence: zhangjian00@sdu.edu.cn; Tel.: +86-531-88361185; Fax: +86-531-88364513 \\ + These authors contributed equally to this work.
}

\begin{abstract}
Plants can remove pollutants through direct absorption and by providing habitats for microbes to stimulate their activities. The aboveground plant biomass is usually harvested to remove pollutants absorbed in plant tissues. However, the effect of plant harvesting during summer on the performance of constructed wetlands and microbial abundance is unclear. In this study, three types of microcosms were set up, including: cleared group (both shoots and roots were harvested), harvested group (only shoots were harvested) and unharvested group. The concentrations of ammonia nitrogen and chemical oxygen demand in the effluent of the harvested group were the lowest. The nitrogen mass balance showed that summer harvesting improved nitrogen absorbance by plants, which was 1.24-times higher than that in the unharvested group. Interestingly, the other losses were taken up by the highest amounts in the cleared group, which were 1.66- and 3.72-times higher than in the unharvested and harvested group, respectively. Quantitative polymerase chain reaction revealed that harvesting of shoots during summer increased the microbial abundance. Additionally, Proteobacteria was the dominant phylum among all bacteria according to pyrosequencing analysis. These results indicate that harvesting of shoots during summer has positive effects on pollutant removal and microbial abundance.
\end{abstract}

Keywords: harvesting; constructed wetlands; microbial population; structure of the microbial community

\section{Introduction}

Constructed wetlands (CWs) have been widely used for wastewater and heavy metal treatment [1] due to their low cost and energy consumption [2]. In CWs, pollutants can be removed by plant uptake, periphyton storage and microbial processes. Plants in CWs play an important role in directly assimilating pollutants and stimulating microbial activities through the provided habitats. Moreover, oxygen and exudates, released from plant roots, can also promote pollutant removal [3]. After remediation, the aboveground biomass of plants is usually harvested to remove the absorbed pollutants in plant tissues [4]. However, Wang et al. [5] found that harvesting in late autumn decreased the oxygen release rate in CWs and showed a negative effect on pollutant removal. Hence, how plant harvesting affects the performance of CWs during summer needs further study.

Harvesting of biomass periodically is a good option for CWs' management, regarding both plant growth, nutrient removal and heavy metal treatment $[4,6]$. The frequency of harvesting depends on the short-term nature of biological storage, and plants should be harvested before nutrients are 
turned soluble and transferred to ground biomass [7]. The interaction of the total biomass and nutrient concentrations of the biomass determines the optimum time of harvests. The plants in CWs are usually harvested in summer, autumn or winter [8]. However, previous studies suggesting the best season to harvest conflict with each other [9,10]. According to Haberl and Perfler [11], we harvested plants in summer. However, summer harvesting may also postpone subsequent plant growth and affect plants radial oxygen loss (ROL) and nutrient transfer from stems to rhizomes [5,10]. Our previous work [5] found that harvesting in late autumn had a negative effect on chemical oxygen demand (COD) and ammonia nitrogen $\left(\mathrm{NH}_{4}{ }^{+}-\mathrm{N}\right)$ removal with lower plant radial oxygen loss, microbial abundance and activity. Besides, the physiological statuses and functions of plants are different between summer and winter. Although we have found that harvesting in late autumn had negative effects on pollutant removal [5], the effects of harvesting in summer are still unclear.

Microbes play the main role in pollutant removal, and plants could enhance microbial activity and abundance by providing oxygen and a carbon source from root-system [12]. Oxygen is transported from aboveground through the rhizome and released into the soil [13], which has a big impact on redox potential [14] and microbial activity [15]. It is reported that about $10 \%-40 \%$ of the net photosynthetic production is released as root exudates, which can stimulate microbial growth and provide a carbon source for bacteria, including denitrifiers. Therefore, we speculated that harvesting of plants may affect the microbial community and further improve the performance of CWs.

Three types of microcosms were set up, including the cleared group, harvested group and unharvested group, to investigate the influence of summer harvesting on the performance of CWs. The microbial population was analyzed using qPCR assays based on 16S rRNA. Besides, the microbial community was also detected by next generation sequencing based on the Miseq platform (Chinese National Human Genome Sequencing Center, Shanghai).

\section{Materials and Methods}

\subsection{Microcosm Wetland System Setup}

Nine laboratory-scale wetland microcosms, set up as Wu et al. [16] described, were operated in Shandong Normal University in Jinan, China $\left(36^{\circ} 40^{\prime} 36^{\prime \prime} \mathrm{N}, 117^{\circ} 3^{\prime} 42^{\prime \prime} \mathrm{E}\right)$, with a sub-humid continental monsoon climate. The hydraulic loading rate of each cycle was $1 \mathrm{~cm} /$ day. The laboratory-scale wetland microcosms and the hydraulic loading rate were set as Wu et al. [16] described. The wetland microcosms were designed as subsurface vertical flow, made of polyvinyl chloride columns and filled with washed gravel and sand (particle size $<2 \mathrm{~mm}$, mainly $\mathrm{Si}_{2} \mathrm{O}_{3}, \mathrm{Al}_{2} \mathrm{O}_{3}, \mathrm{Fe}_{2} \mathrm{O}_{3}$ ) (Figure 1) to avoid the effect of pollutants absorbed on their surface. Both gravel and sand were obtained from an unpolluted river. Phragmites australis were obtained from Nansi Lake, and 20 rhizomes were planted per microcosm. The CWs were designed to undertake advanced treatment of sewage. In China, the influent of the CWs was usually effluent from municipal sewage plants, and the sewage is post-primary (B) domestic wastewater [17]. Therefore, specific pollutant concentrations were chosen to simulate the post-primary (B) domestic wastewater. The influent had $15.94 \pm 0.15 \mathrm{mg} / \mathrm{L} \mathrm{NH}_{4}{ }^{+}-\mathrm{N}$ and $61.86 \pm 1.98 \mathrm{mg} / \mathrm{L} \mathrm{COD}$. The experiment cycle was 7 days. At each cycle, $4 \mathrm{~L}$ of synthetic wastewater were added into each microcosm to keep the water level always below the sand surface [5]. The wetland microcosms had been operated for 6 months before the experiment. At the beginning of the experiment, both plant shoots and roots were harvested in the cleared group; only plant shoots were harvested in the harvested group; while the unharvested group was used as the control. Each group has three replicates. 


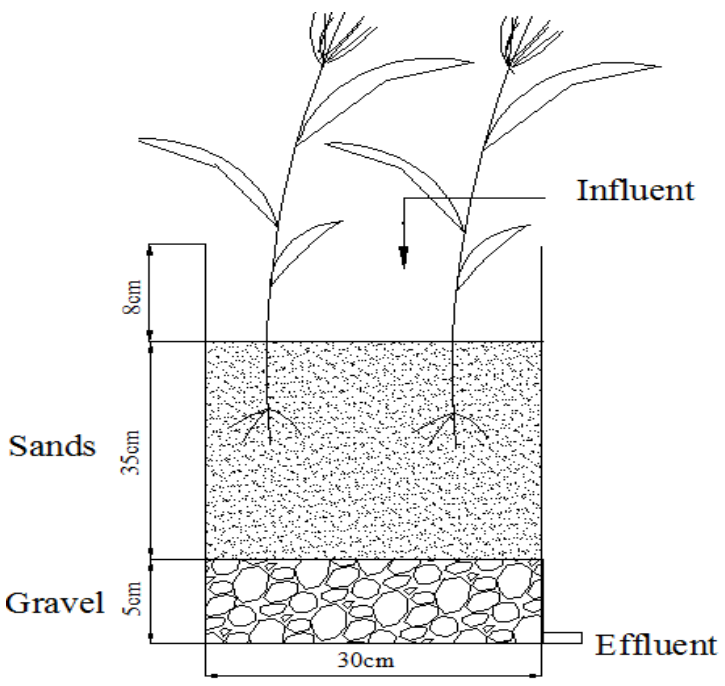

Figure 1. The size parameters of the wetland microcosms.

\subsection{Sampling}

Water samples were collected from influent and effluent and stored in 100-mL sterile plastic bottles. Then, these samples were brought to the laboratory immediately for further analysis. The substrate samples were gained from each wetland microcosm at the end of the experiment. Before sampling, each microcosm was completely drained, and the substrates were collected from the top layer $(5 \mathrm{~cm}-10 \mathrm{~cm})$ using a sterilized spoon [18]. Samples were contained in $5-\mathrm{mL}$ sterilized tubes and stored at $-20^{\circ} \mathrm{C}$ for microbial analysis.

\subsection{Analysis}

\subsubsection{Physical and Chemical Analysis}

The concentrations of dissolved oxygen (DO) and temperature (T) were measured in situ with a DO meter (HQ40d 53LED ${ }^{\mathrm{TM}}, \mathrm{HACH}$, Loveland, CO, USA) at the end of each cycle. The water samples were brought to the laboratory and analyzed immediately for $\mathrm{COD}, \mathrm{NH}_{4}{ }^{+}-\mathrm{N}$, nitrate nitrogen $\left(\mathrm{NO}_{3}{ }^{-} \mathrm{N}\right)$ and nitrite nitrogen $\left(\mathrm{NO}_{2}{ }^{-}-\mathrm{N}\right)$. All of the above parameters were determined based on standard methods [5].

\subsubsection{Nitrogen Analysis}

The mass balance approach was used to assess the effect of biomass harvesting on nitrogen removal. It contained: the amounts of nitrogen imported and exported from the microcosm systems; the amounts of nitrogen assimilated by plants; the amounts of nitrogen absorbed by the substrate; other losses, including ammonia volatilization, $\mathrm{N}_{2} \mathrm{O}$ and $\mathrm{N}_{2}$ emission [19]. The calculative pattern for the nitrogen mass balance is shown below [20]:

$$
\begin{gathered}
\mathrm{N}_{\text {input }}(\mathrm{mgN})=\mathrm{N}_{\text {output }}(\mathrm{mg} \mathrm{N}) \\
\mathrm{N}_{\text {input }}(\mathrm{mg} \mathrm{N})=\mathrm{N}_{\text {influent }}(\mathrm{mgN}) \\
\mathrm{N}_{\text {influent }}(\mathrm{mg} \mathrm{N})=\sum \mathrm{C}_{\mathrm{i}} \cdot \mathrm{V}_{\mathrm{i}} \\
\mathrm{N}_{\text {effluent }}(\mathrm{mg} \mathrm{N})=\sum \mathrm{C}_{\mathrm{j}} \cdot \mathrm{V}_{\mathrm{j}}
\end{gathered}
$$


where $C_{i / j}$ is the influent/effluent concentrations in $\mathrm{mg} / \mathrm{L} ; \mathrm{V}_{\mathrm{i} / \mathrm{j}}$ is the volume of the influent/effluent in liters of each cycle.

$$
\begin{gathered}
\mathrm{N}_{\text {output }}(\mathrm{mgN})=\mathrm{N}_{\text {effluent }}(\mathrm{mgN})+\mathrm{N}_{\text {plant }}(\mathrm{mgN})+\mathrm{N}_{\text {substrate }}(\mathrm{mgN})+\mathrm{N}_{\text {other }}(\mathrm{mgN}) \\
\mathrm{N}_{\text {plant }}(\mathrm{mgN})=\left(\mathrm{M}_{\text {end }} \mathrm{C}_{\text {end }}-\mathrm{M}_{\text {initial }} \mathrm{C}_{\text {initial }}\right)
\end{gathered}
$$

where $M_{\text {end }}$ and $M_{\text {initial }}$ are the average dry weights of the biomass; $C_{\text {end }}$ and $C_{\text {initial }}$ are the average $N$ concentrations in plants as a percentage of dry weight at the end and in the initial stage.

$$
\mathrm{N}_{\text {substrate }}(\mathrm{mgN})=\mathrm{M}_{\text {substrate }} \mathrm{C}_{\text {substrate }}
$$

where $M_{\text {substrate }}$ is the average dry weight of the substrates; and $C_{\text {substrate }}$ is the average $\mathrm{N}$ concentration in the substrate as a percentage of dry weight.

Substrate and plant samples were taken from both the harvested and unharvested group at the beginning and end of the experiment. The harvested biomass was rinsed with distilled water and dried at $80^{\circ} \mathrm{C}$ for $72 \mathrm{~h}$ until constant weight [21]. All samples were ground to a fine powder using a Micro Plant Grinding Machine and then sieved through a 100 mesh. Elemental analysis was conducted at the Energy Research Institute of Shandong Academy of Sciences using an elementary analyzer (vario MACRO cube, Elementar, Germany) equipped with a thermal conductivity detector.

\subsubsection{Microbial Analysis}

The DNA samples were extracted from the substrate samples using the MOBIO PowerSand ${ }^{\mathrm{TM}}$ DNA Isolation Kits (MoBio Laboratories, Inc., Carlsbad, CA, USA). The yields of DNA were measured by a Nanodrops ND-1000 UV-VIS spectrophotometer (NanoDrop Technologies, Wilmington, DE, USA). The extracted DNA samples were stored at $-20^{\circ} \mathrm{C}$ before analysis.

Quantitative polymerase chain reaction (qPCR) was carried out using a Roche LC-480 real-time PCR system (Roche, Shanghai, China). The 16S rRNA genes were quantified using the primers Eub341F/Eub534R [22]. The standard curves were generated from a 10-fold serial dilution of plasmid DNA containing specific genes. The $20 \mu \mathrm{L}$ of the reaction mixture consisted of $10 \mu \mathrm{L}$ of SYBR ${ }^{\circledR}$ Premix $\operatorname{Ex~Taq}^{\mathrm{TM}}$ (TaKaRa, Dalian, China ), $0.4 \mu \mathrm{L}$ of the corresponding primers, $7.2 \mu \mathrm{L}$ of nuclease-free water and $2 \mu \mathrm{L}$ of template DNA. The qPCR program is shown below: initial denaturation for $30 \mathrm{~s}$ at $95^{\circ} \mathrm{C}$, followed by 40 cycles of $95^{\circ} \mathrm{C}$ for $10 \mathrm{~s}, 60^{\circ} \mathrm{C}$ for $15 \mathrm{~s}$ and $72{ }^{\circ} \mathrm{C}$ for $20 \mathrm{~s}$. The final data of qPCR were generated through Abs Quant/2nd Derivative Max provided with the Roche LC-480 system [5].

\subsubsection{Pyrosequencing and Data Analysis}

Pyrosequencing technologies have initiated new frontiers in microbial community analysis. In this study, the DNA samples were sequenced on the rare method detailed by Wang et al. Pyrosequencing was conducted at the Chinese National Human Genome Sequencing Center (Shanghai) and calculated according to Mothur analysis $[23,24]$.

\subsubsection{Statistical Analyses}

In the statistical analyses, only steady-state data were used to calculate the mean and standard deviation values for different groups. All statistical analyses of the correlation between different variables were carried out using SPSS 17.0. A one-way analysis of variance (ANOVA) was performed to access the significant correlations of microbe values among different groups. In all tests, differences were considered statistically significant when $p<0.05$. Additionally, the results were displayed as the mean \pm the standard deviation. 


\section{Results and Discussion}

\subsection{Effluent Water Parameters}

The characteristics of the effluent in different groups are presented in Table 1. The harvested group had higher concentrations of DO than the other groups. As the main oxygen sources, ROL and surface reaeration affect DO concentrations greatly $[5,25,26]$. In the presence of plants root, the harvested group had higher DO than the cleared group. Plants in the harvested group had less stems than the unharvested group, which created better convection conditions and led to higher surface reaeration rates. Moreover, the withered stems in the harvested group became connections between air and roots and could absorb atmospheric air into the underground roots by Venturi-induced convection [25,27]. The removal efficiency of $\mathrm{NH}_{4}{ }^{+}-\mathrm{N}$ and COD in the harvested group was the highest. Summer harvesting showed a positive effect on $\mathrm{COD}$ and $\mathrm{NH}_{4}{ }^{+}-\mathrm{N}$ removal, and there is a positive correlation between the removal efficiency of pollutants and DO concentrations in effluent $\left(r^{2}>0.635\right)$. The plants harvested in summer had higher removal efficiency of nitrogen than that harvested in autumn according to Toet et al. [28]. According to Haberl and Perfler [11], plants harvested in summer would obtain at least three-times higher removal of nitrogen than plants harvested in autumn and winter. Nikolausz et al. [29] proved that most of the oxygen released by roots was used in the processes of the degradation of organic matter and nitrification. The unharvested group had higher pollutant removal efficiency than the cleared group with similar DO concentrations. Plants in the unharvested group have roots to provide habitats for microbes, as well as the oxygen released by the plants affecting the redox states. Based on the different redox states in the root zone, microbial oxidation and reduction processes occur simultaneously [30]. Studies have proven that the nitrification process and the decomposition of simple organic matter can be limited by low oxygen availability, because they are redox-sensitive processes [31].

Table 1. The effluent characteristics in different groups (mean $\pm \mathrm{SD}, n=3$ ). DO, dissolved oxygen.

\begin{tabular}{|c|c|c|c|c|c|c|}
\hline \multirow[b]{2}{*}{ Group } & \multicolumn{6}{|c|}{ Parameter } \\
\hline & $\operatorname{COD}(\mathrm{mg} / \mathrm{L})$ & $\begin{array}{c}\mathrm{NH}_{4}{ }^{+}-\mathrm{N} \\
(\mathrm{mg} / \mathrm{L})\end{array}$ & $\begin{array}{c}\text { Removal } \\
\text { Efficiency of } \\
\text { COD }(\%)\end{array}$ & $\begin{array}{c}\text { Removal } \\
\text { Efficiency of } \\
\mathrm{NH}_{4}{ }^{+}-\mathrm{N}(\%)\end{array}$ & $\mathrm{T}\left({ }^{\circ} \mathrm{C}\right)$ & $\mathrm{DO}(\mathrm{mg} / \mathrm{L})$ \\
\hline Unharvested & $22.75 \pm 2.91$ & $1.17 \pm 0.55$ & $92.64 \pm 3.35$ & $63.23 \pm 4.13$ & $24.36 \pm 3.87$ & $1.63 \pm 0.56$ \\
\hline Harvested & $18.35 \pm 5.23$ & $1.00 \pm 0.44$ & $93.70 \pm 2.73$ & $70.65 \pm 7.47$ & $24.54 \pm 4.03$ & $2.00 \pm 0.38$ \\
\hline Cleared & $26.14 \pm 4.43$ & $1.97 \pm 0.52$ & $87.62 \pm 0.26$ & $57.75 \pm 6.40$ & $25.41 \pm 4.84$ & $1.63 \pm 0.38$ \\
\hline
\end{tabular}

\subsection{Nitrogen Mass Balance}

The nitrogen mass balance in different groups through the experiment is shown in Table 2. The total nitrogen input into wetlands was $101.21 \mathrm{mg} \mathrm{N} / \mathrm{m}^{2} /$ day, which was calculated according to the amount of nitrogen in the influent. As shown, the nitrogen in the effluent was 13.59, 6.97 and $8.15 \mathrm{mg} \mathrm{N} / \mathrm{m}^{2} /$ day for the cleared group, the harvested group and the unharvested group, respectively. The nitrogen assimilated by plants was 33.21-41.12 $\mathrm{mg} \mathrm{N} / \mathrm{m}^{2} /$ day. Furthermore, summer harvesting improved nitrogen absorbance by plants, which was 1.24-times higher than that in the unharvested group. The plant uptake took up 40.63\%, which was less than the 55\% reported by Breen [32]. However, this was accordant with what Reddy and DeBusk [33] reported, which varied from $16 \%-75 \%$ in various wetlands. The high plant uptake proportion was due to the rapid biomass growth and influent quality. Additionally, summer harvesting of shoots could lead to the high plant biomass productivity [34]. 
Table 2. Nitrogen mass balance in different groups through the experiment.

\begin{tabular}{|c|c|c|c|c|c|c|c|}
\hline \multirow{2}{*}{ Group } & \multirow{2}{*}{$\begin{array}{l}\text { Plant Dry } \\
\text { Mass (g) }\end{array}$} & \multirow{2}{*}{ Plant Biomass (g) } & \multirow{2}{*}{$\begin{array}{c}\begin{array}{c}\text { Input Load } \\
\text { (mg N/m²/day) }\end{array} \\
\text { Influent }\end{array}$} & \multicolumn{4}{|c|}{ Output Load (mg N/m²/day) } \\
\hline & & & & Effluent & Sediment & Plant Uptake & Other Losses \\
\hline Cleared & 0 & 0 & 101.21 & 13.59 & 38.97 & 0 & 48.65 \\
\hline Harvested & 13.18 & 16.48 & 101.21 & 6.97 & 40.06 & 41.12 & 13.06 \\
\hline Unharvested & 20.34 & 27.12 & 101.21 & 8.15 & 30.54 & 33.21 & 29.31 \\
\hline
\end{tabular}

Nitrogen accumulated in sediment was $30.54-40.06 \mathrm{mg} \mathrm{N} / \mathrm{m}^{2} /$ day. Compared to the unharvested group, the cleared group and the harvested group had more nitrogen distribution in the sediment. The nitrogen was immobilized by sediment adsorption and microbial assimilation, which was higher than the $34.4 \%$ reported by Wu et al. [19]. $\mathrm{NH}_{4}{ }^{+}-\mathrm{N}$ in solution can be adsorbed through a cation exchange reaction with the substrate. The extent is influenced by the amount of clays, the content of the substrate organic matter and the presence of plants [35].

The other losses, which could be due to other microbial reactions, adsorption and ammonia volatilization, were obtained by deducting other nitrogen removal from the total nitrogen input into wetlands [34]. Interestingly, the other losses were taken up by the highest amount in the cleared group, which was 1.66- and 3.72-times higher than in the unharvested and harvested group, respectively. The reasons will be discussed in Section 3.3.

\subsection{Microbial Abundance and Community}

Figure 2 presents the differences of the total bacteria (16S rRNA) abundance in soil samples, for which the harvested group was the highest, $8.26 \pm 0.11 \times 10^{10}$ copies/g soil, followed by the unharvested group and the cleared group with $2.78 \pm 0.51 \times 10^{7}$ and $1.90 \pm 0.33 \times 10^{7}$ copies/g soil, respectively. The differences were significant $(p<0.05)$. The results showed that plant harvesting improved convection conditions and enhanced reaeration rates, which accelerated the breeding of aerobic or facultative bacteria [36]. On the other hand, better light conditions with less shoots in the harvested group than the unharvested group stimulated the breeding of Cyanobacteria and photosynthetic bacteria (Figure 3), which provide heterotrophic bacteria with oxygen and might establish a stable ecological symbiosis [24]. Therefore, the harvested group had higher microbial abundance than any other group. Harvesting of shoots during summer increased the microbial abundance, which is in contrast to the results that harvesting in late autumn exhibited negative effects on the microbial population and activity during the following winter [5]. However, the microbial abundance of the cleared group decreased because of losing numerous microhabitats provided by plant root [36] and the organic carbons secreted by roots, which makes microbes more active and efficient in nutrient removal [21]. However, the high proportion of other losses in the cleared group need further study by microbial community analysis.

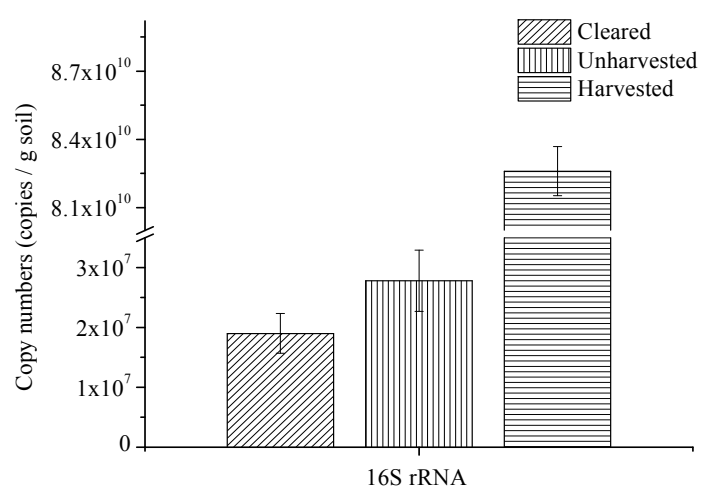

Figure 2. Copy numbers for $16 \mathrm{~S}$ rRNA of total bacterial in soil samples. Error bars represent the standard error $(n=3)$. 
The microbial composition of the total bacteria is shown in Figure 3. By using Meseq, more than 25,000 effective sequence tags were yielded for each sample, resulting in 231,348 effective sequences of $250 \mathrm{bp}$ in total of all samples. The coverage of microbial species in all samples was higher than $98 \%$, which indicated that the sequencing was reliable and effective to reflect the microbial species in the wetland microcosms [37]. A total of 40 phyla were identified, in which Proteobacteria, Acidobacteria, Actinobacteria, Bacteroidetes, Cyanobacteria, Planctomycetes and Chloroflexi comprised the largest proportions.

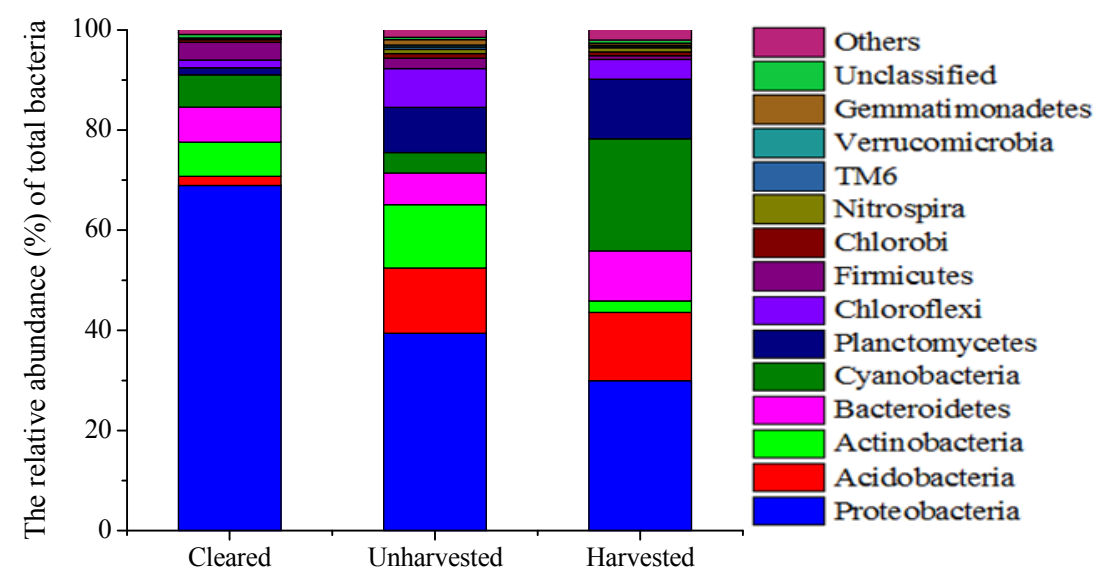

Figure 3. The relative abundance (\%) of total bacteria for different groups by phylum.

Proteobacteria was the dominant phylum among all bacteria, with the highest proportion in the cleared group (68.92\%), followed by the unharvested and harvested groups with $39.41 \%$ and $29.92 \%$, respectively. The proportion was consistent with the amounts of nitrogen removed by other losses $\left(r^{2}=0.972\right)$. The Proteobacteria phylum includes a large amount of bacterial metabolic diversity, which plays an important role in worldwide nitrogen cycling. This may be a factor for why the cleared group had the highest amount of converted $\mathrm{NH}_{4}{ }^{+}$to $\mathrm{N}_{2}$ and $\mathrm{N}_{2} \mathrm{O}$.

The proportion of Cyanobacteria in the harvested group (22.40\%) was higher than the unharvested group $(4.12 \%)$ and the cleared group $(6.46 \%)$. The synergistic effect of cyanobacteria/microalgae and bacteria can be effective in the degradation of organic and inorganic pollutants and the removal of nutrients from wastewaters [38]. This may be the main factor that led to the highest COD removal efficiency in the harvested group. The harvested group with less shoots than the unharvested group decreased the shelter of plants, which stimulated the breeding of Cyanobacteria [24] and provided more available carbon for denitrification. However, as the microbial community structure of the cleared group has been destroyed, the accumulation of Cyanobacteria needed a longer time. The proportion of Nitrospirae in the unharvested group and the harvested group was $0.86 \%$ and $0.83 \%$, respectively. There is no obvious difference between them.

Proteobacteria play active roles in biodegradation of organic pollutants and various biogeochemical processes [39]. As the biggest phylum of the total bacteria, detailed class studies were processed in different groups (Table 3). Members of the alpha-Proteobacteria, which are associated with reed roots and influenced by oxygen and exudates [40], play a necessary role in nitrogen-fixing [41]. Alpha-Proteobacteria was dominant in the harvested group and the unharvested group. However, the cleared group had the highest proportion of beta-Proteobacteria. The presence of large amounts of beta-Proteobacteria indicated a ready source of oxidizable ammonia [42] and degradation of complex organic compounds [43]. Besides, the cleared group had much more gamma-Proteobacteria, which exhibits broad ranges of aerobicity, chemoautotrophism and photoautotrophism [44]. $\mathrm{NH}_{4}{ }^{+}-\mathrm{N}$ can be oxidized to $\mathrm{NO}_{3}{ }^{-}$driven by nitrifying bacteria and photoautotrophic processes [45]. Thus, the cleared group can maintain a high $\mathrm{NH}_{4}{ }^{+}-\mathrm{N}$ removal with a higher proportion of gamma-Proteobacteria. 
Table 3. The relative sequence abundance (\%) of Proteobacteria for different microcosms by class.

\begin{tabular}{cccc}
\hline Class & Unharvested & Harvested & Cleared \\
\hline Alpha & 15.30 & 9.03 & 4.63 \\
Beta & 11.21 & 9.26 & 16.06 \\
Delta & 6.18 & 3.86 & 2.78 \\
Gamma & 6.57 & 7.60 & 45.40 \\
Unclassified & 0.01 & 0.03 & 0.06 \\
Total & 39.41 & 29.92 & 68.92 \\
\hline
\end{tabular}

\section{Conclusions}

Our results indicated that harvesting of biomass has positive effects on pollutant removal and microbial abundance during summer. However, harvesting could change the microbial community by decreasing the relative abundance of Proteobacteria. In summary, harvesting of biomass in summer is a proper way to enhance pollutant removal. Besides, the mechanism of root exudates and radial oxygen loss in this process needs to be further studied.

Acknowledgments: We gratefully acknowledge financial support by the National Science Foundation of China (21007032 and 21307078) and the Fundamental Research Funds of Shandong University (2014JC023).

Author Contributions: The experimental work was conducted by Zhongchen Yang, Qian Wang, Jian Zhang, Huijun Xie and Suping Feng. The manuscript was written by Zhongchen Yang, Huijun Xie and Qian Wang. Data analysis was performed by Zhongchen Yang and Huijun Xie. All authors approved the final version of the article, including the authorship list.

Conflicts of Interest: The authors declare no conflict of interest.

\section{References}

1. Gikas, P.; Ranieri, E.; Tchobanoglous, G. Removal of iron, chromium and lead from waste water by horizontal subsurface flow constructed wetlands. J. Chem. Technol. Biotechnol. 2013, 88, 1906-1912.

2. Vymazal, J. Constructed Wetlands for Wastewater Treatment: Five Decades of Experience. Environ. Sci. Technol. 2010, 45, 61-69. [PubMed]

3. Dickopp, J.; Kazda, M.; Č́̌žková, H. Differences in rhizome aeration of Phragmites australis in a constructed wetland. Ecol. Eng. 2011, 37, 1647-1653. [CrossRef]

4. Jinadasa, K.; Tanaka, N.; Sasikala, S.; Werellagama, D.; Mowjood, M.; Ng, W. Impact of harvesting on constructed wetlands performance-A comparison between Scirpus grossus and Typha angustifolia. J. Environ. Sci. Health 2008, 43, 664-671. [CrossRef] [PubMed]

5. Wang, Q.; Xie, H.; Zhang, J.; Liang, S.; Ngo, H.H.; Guo, W.; Liu, C.; Zhao, C.; Li, H. Effect of plant harvesting on the performance of constructed wetlands during winter: Radial oxygen loss and microbial characteristics. Environ. Sci. Pollut. Res. 2014, 22, 7476-7484. [CrossRef] [PubMed]

6. Ranieri, E.; Gikas, P. Effects of plants for reduction and removal of hexavalent chromium from a contaminated soil. Water Air Soil Pollut. 2014, 225, 1-9. [CrossRef]

7. Gearheart, R.A. Use of constructed wetlands to treat domestic wastewater, City of Arcata, California. Water Sci. Technol. 1992, 26, 1625-1637.

8. Bald, M.L. Plant Harvesting from a Constructed Wetland: Nutrient Removal and Plant Attributes; Department of Environmental Biology, University of Adelaide: Adelaide, Australia, 2001.

9. Gryseels, M. Nature management experiments in a derelict reed marsh. I: Effects of winter cutting. Biol. Conserv. 1989, 47, 171-193. [CrossRef]

10. Asaeda, T.; Karunaratne, S. Dynamic modeling of the growth of Phragmites australis: Model description. Aquat. Bot. 2000, 67, 301-318. [CrossRef]

11. Haberl, R.; Perfler, R. Seven years of research work and experience with wastewater treatment by a reed bed system, Constructed wetlands in water pollution control. In Proceedings of the International Conference on the Use of Constructed Wetlands in Water Pollution Control, Cambridge, UK, 24-28 September 1990; p. 205. 
12. Jensen, S.I.; Kühl, M.; Priemé, A. Different bacterial communities associated with the roots and bulk sediment of the seagrass Zostera marina. FEMS Microbiol. Ecol. 2007, 62, 108-117. [CrossRef] [PubMed]

13. Stottmeister, U.; Wießner, A.; Kuschk, P.; Kappelmeyer, U.; Kästner, M.; Bederski, O.; Müller, R.; Moormann, H. Effects of plants and microorganisms in constructed wetlands for wastewater treatment. Biotechnol. Adv. 2003, 22, 93-117. [CrossRef] [PubMed]

14. Białowiec, A.; Davies, L.; Albuquerque, A.; Randerson, P.F. The influence of plants on nitrogen removal from landfill leachate in discontinuous batch shallow constructed wetland with recirculating subsurface horizontal flow. Ecol. Eng. 2012, 40, 44-52. [CrossRef]

15. Ueckert, J.; Hurek, T.; Fendrik, I.; Niemann, E.-G. Radial gas diffusion from roots of rice (Oryza sativa L.) and Kallar grass (Leptochloa fusca L. Kunth), and effects of inoculation with Azospirillum brasilense Cd. Plant Soil 1990, 122, 59-65. [CrossRef]

16. Wu, H.; Zhang, J.; Li, P.; Zhang, J.; Xie, H.; Zhang, B. Nutrient removal in constructed microcosm wetlands for treating polluted river water in northern China. Ecol. Eng. 2011, 37, 560-568. [CrossRef]

17. Taylor, C.R.; Hook, P.B.; Stein, O.R.; Zabinski, C.A. Seasonal effects of 19 plant species on COD removal in subsurface treatment wetland microcosms. Ecol. Eng. 2011, 37, 703-710. [CrossRef]

18. Calheiros, C.; Teixeira, A.; Pires, C.; Franco, A.R.; Duque, A.F.; Crispim, L.F.C.; Moura, S.C.; Castro, P.M.L. Bacterial community dynamics in horizontal flow constructed wetlands with different plants for high salinity industrial wastewater polishing. Water Res. 2010, 44, 5032-5038. [CrossRef] [PubMed]

19. Wu, H.; Zhang, J.; Wei, R.; Liang, S.; Li, C.; Xie, H. Nitrogen transformations and balance in constructed wetlands for slightly polluted river water treatment using different macrophytes. Environ. Sci. Pollut. Res. 2013, 20, 443-451. [CrossRef] [PubMed]

20. Wu, H.; Zhang, J.; Li, C.; Fan, J.; Zou, Y. Mass Balance Study on Phosphorus Removal in Constructed Wetland Microcosms Treating Polluted River Water. CLEAN Soil Air Water 2013, 41, 844-850. [CrossRef]

21. Lin, Y.-F.; Jing, S.-R.; Wang, T.-W.; Lee, D.-Y. Effects of macrophytes and external carbon sources on nitrate removal from groundwater in constructed wetlands. Environ. Pollut. 2002, 119, 413-420. [CrossRef]

22. Muyzer, G.; De Waal, E.C.; Uitterlinden, A.G. Profiling of complex microbial populations by denaturing gradient gel electrophoresis analysis of polymerase chain reaction-amplified genes coding for 16S rRNA. Appl. Environ. Microbiol. 1993, 59, 695-700. [PubMed]

23. Schloss, P.D.; Westcott, S.L.; Ryabin, T.; Hall, J.R.; Hartmann, M.; Hollister, E.B.; Lesniewski, R.A.; Oakley, B.B.; Parks, D.H.; Robinson, C.J.; et al. Introducing mothur: Open-source, platform-independent, community-supported software for describing and comparing microbial communities. Appl. Environ. Microbiol. 2009, 75, 7537-7541. [CrossRef] [PubMed]

24. Wang, Q.; Xie, H.; Ngo, H.H.; Guo, W.; Zhang, J.; Liu, C.; Liang, S.; Hu, Z.; Yang, Z.; Zhao, C. Microbial abundance and community in subsurface flow constructed wetland microcosms: Role of plant presence. Environ. Sci. Pollut. Res. 2015. [CrossRef] [PubMed]

25. Brix, H. Functions of macrophytes in constructed wetlands. Water Sci. Technol. 1994, 29, 71-78.

26. Huang, J.; Cai, W.; Zhong, Q.; Wang, S. Influence of temperature on micro-environment, plant eco-physiology and nitrogen removal effect in subsurface flow constructed wetland. Ecol. Eng. 2013, 60, 242-248. [CrossRef]

27. Armstrong, J.; Armstrong, W.; Beckett, P.M. Phragmites australis: Venturi-and humidity-induced pressure flows enhance rhizome aeration and rhizosphere oxidation. New Phytol. 1992, 120, 197-207. [CrossRef]

28. Toet, S.; Bouwman, M.; Cevaal, A.; Verhoeven, J.T.A. Nutrient removal through autumn harvest of Phragmites australis and Thypha latifolia shoots in relation to nutrient loading in a wetland system used for polishing sewage treatment plant effluent. J. Environ. Sci. Health 2005, 40, 1133-1156. [CrossRef]

29. Nikolausz, M.; Kappelmeyer, U.; Székely, A.; Rusznyák, A.; Márialigeti, K.; Kästner, M. Diurnal redox fluctuation and microbial activity in the rhizosphere of wetland plants. Eur. J. Soil Biol. 2008, 44, 324-333. [CrossRef]

30. Overmann, J.; van Gemerden, H. Microbial interactions involving sulfur bacteria: Implications for the ecology and evolution of bacterial communities. FEMS Microbiol. Rev. 2000, 24, 591-599. [CrossRef] [PubMed]

31. Wu, M.-Y.; Franz, E.H.; Chen, S. Oxygen fluxes and ammonia removal efficiencies in constructed treatment wetlands. Water Environ. Res. 2001, 73, 661-666. [CrossRef] [PubMed]

32. Breen, P.F. A mass balance method for assessing the potential of artificial wetlands for wastewater treatment. Water Res. 1990, 24, 689-697. [CrossRef] 
33. Reddy, K.R.; Debusk, W.F. Nutrient storage capabilities of aquatic and wetland plants. In Aquatic Plants for Wastewater Treatment \& Resource Recovery; Magnolia Public Inc.: Orlando, FL, USA, 1987; pp. 337-353.

34. Sawaittayothin, V.; Polprasert, C. Nitrogen mass balance and microbial analysis of constructed wetlands treating municipal landfill leachate. Bioresour. Technol. 2007, 98, 565-570. [CrossRef] [PubMed]

35. Vymazal, J. Removal of nutrients in various types of constructed wetlands. Sci. Total Environ. 2007, 380, 48-65. [CrossRef] [PubMed]

36. Gagnon, V.; Chazarenc, F.; Comeau, Y.; Brisson, J. Influence of macrophyte species on microbial density and activity in constructed wetlands. Water Sci. Technol. 2007, 56, 249-254. [CrossRef] [PubMed]

37. Wang, C.; Mitsuya, Y.; Gharizadeh, B.; Ronaghi, M.; Shafer, R.W. Characterization of mutation spectra with ultra-deep pyrosequencing: Application to HIV-1 drug resistance. Genome Res. 2007, 17, 1195-1201. [CrossRef] [PubMed]

38. Subashchandrabose, S.R.; Ramakrishnan, B.; Megharaj, M.; Venkateswarlu, K.; Naidu, R. Consortia of cyanobacteria/microalgae and bacteria: Biotechnological potential. Biotechnol. Adv. 2011, 29, 896-907. [CrossRef] [PubMed]

39. Cheng, W.; Zhang, J.; Wang, Z.; Wang, M.; Xie, S. Bacterial communities in sediments of a drinking water reservoir. Ann. Microbiol. 2014, 64, 875-878. [CrossRef]

40. Herrmann, M.; Saunders, A.M.; Schramm, A. Archaea dominate the ammonia-oxidizing community in the rhizosphere of the freshwater macrophyte Littorella uniflora. Appl. Environ. Microbiol. 2008, 74, 3279-3283. [CrossRef] [PubMed]

41. Bodelier, P.L.; Dedysh, S.N. Microbiology of wetlands. Front. Microbiol. 2013. [CrossRef]

42. Araya, R.; Tani, K.; Takagi, T.; Yamaguchi, N.; Nasu, M. Bacterial activity and community composition in stream water and biofilm from an urban river determined by fluorescent in situ hybridization and DGGE analysis. FEMS Microbiol. Ecol. 2003, 43, 111-119. [CrossRef] [PubMed]

43. Kirchman, D.L. The ecology of Cytophaga-Flavobacteria in aquatic environments. FEMS Microbiol. Ecol. 2002, 39, 91-100. [CrossRef]

44. Williams, K.P.; Gillespie, J.J.; Sobral, B.W.; Nordberg, E.K.; Snyder, E.E.; Shallom, J.M.; Dickerman, A.W. Phylogeny of gammaProteobacteria. J. Bacteriol. 2010, 192, 2305-2314. [CrossRef] [PubMed]

45. Ebeling, J.M.; Timmons, M.B.; Bisogni, J. Engineering analysis of the stoichiometry of photoautotrophic, autotrophic, and heterotrophic removal of ammonia-nitrogen in aquaculture systems. Aquaculture 2006, 257, 346-358. [CrossRef]

(C) 2016 by the authors; licensee MDPI, Basel, Switzerland. This article is an open access article distributed under the terms and conditions of the Creative Commons by Attribution (CC-BY) license (http://creativecommons.org/licenses/by/4.0/). 